\title{
The freshwater medusa, Craspedacusta sowerbii, in Matoaka Lake, Williamsburg, Virginia
}

Ernest F. Tresselt

Virginia Fisheries Laboratory

Follow this and additional works at: https://scholarworks.wm.edu/vimsarticles

Part of the Terrestrial and Aquatic Ecology Commons, and the Zoology Commons

\section{Recommended Citation}

Tresselt, Ernest F., "The freshwater medusa, Craspedacusta sowerbii, in Matoaka Lake, Williamsburg, Virginia" (1950). VIMS Articles. 1772.

https://scholarworks.wm.edu/vimsarticles/1772 


\section{WILEY}

\section{ECOLOGICAL SOCIETY OF AMERICA}

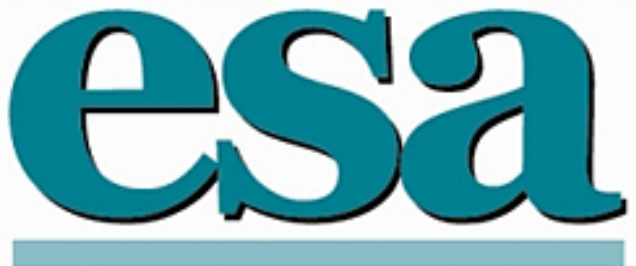

The Freshwater Medusa, Craspedacusta Sowerbii, in Matoaka Lake, Williamsburg, Virginia Author(s): Ernest F. Tresselt

Source: Ecology, Vol. 31, No. 3 (Jul., 1950), p. 478

Published by: Wiley on behalf of the Ecological Society of America

Stable URL: https://www.jstor.org/stable/1931504

Accessed: 10-10-2019 13:06 UTC

JSTOR is a not-for-profit service that helps scholars, researchers, and students discover, use, and build upon a wide range of content in a trusted digital archive. We use information technology and tools to increase productivity and facilitate new forms of scholarship. For more information about JSTOR, please contact support@jstor.org.

Your use of the JSTOR archive indicates your acceptance of the Terms \& Conditions of Use, available at https://about.jstor.org/terms

Wiley, Ecological Society of America are collaborating with JSTOR to digitize, preserve and extend access to Ecology 


\section{THE FRESHWATER MEDUSA, CRASPEDACUSTA SOWERBII, IN MATOAKA LAKE, WILLIAMSBURG, VIRGINIA}

The freshwater jellyfish, Craspedacusta sowcrbii Lankester, has been described from at least 19 of the 48 states (Schmitt, '39). In spite of an apparently widespread distribution it is sufficiently rare that records of its occurrence are noteworthy.

Approximately 200 medusae of this species were seen in Matoaka Lake, Williamsburg, Va., on July 18, 1949. On August 1, 1949, the lake was revisited. About 25 individuals were observed in a different part of the lake.

Matoaka Lake is a small, artificial body of water about 57 acres in area. Its maximum depth is about 21 feet. The medusae were found near the surface in the open part of the lake where the water was deep.

There is no previous record of the occurrence of Craspedacusta sowerbii in Matoaka Lake. The freshwater jellyfish has, however, been reported in other parts of Virginia. Schmitt ('39) reported that specimens of the medusa were collected in several quarries around Richmond in 1933, 1935, 1936, and 1937. Other specimens were found in a goldfish pond in Alexandria, Virginia, in 1933. Hamaker and Milne ('37) reported Craspedacusta from Crystal Lake, near Lynchburg, Virginia.

Specimens from Matoaka Lake were sent to the United States National Museum and were identified by Dr. Ralph W. Dexter of Kent State University.

\section{Literature Cited}

Hamaker, J. I., and L. J. Milne. 1937. Freshwater medusae in Virginia. Science, 86 (2238) : 494.

Schmitt, W. L. 1939. Freshwater jellyfish records since 1932. Amer. Nat., 73 (744) : 83-89.

ERnEst F. TRESSELT

Virginia Fisheries Laboratory, Gloucester Point, Virginia

\section{PARIS ECOLOGY COLLOQUIUM}

As one of a series of international colloquia, the Centre National de la Recherche Scientifique, with the cooperation of the Rockefeller Foundation, sponsored a colloquium titled "Ecologie des Groupements Animaux et Mixtes" in Paris from February 20 to 25, 1950. Professors Prenant and Pacaud of the Sorbonne made most of the arrangements. Two half-day sessions were held each day. Ten such sessions met at the Curie Institute, one at the Trappes Meteorological Station, and the final session in the Cauchy Amphitheater of the Sorbonne. The size of the audience ranged from 40 to 70 persons.

Only two or three papers were presented at each half-day session, and as a consequence there was ample time for discussion, which often proved lively and stimulating. Contributions covered a wide variety of terrestrial, marine, and fresh-water phases of animal ecology and general ecology; the majority were of a summarizing or synthesis nature, but a few dealt with narrow and specific phases of ecology. Most of the papers were delivered in French or English, but a few were given in German. An able interpreter implemented the discussion following each paper.

The tenor of the Colloquium and the many informal conferences were truly international and cooperative. Sixteen papers were given by representatives from France, four from England, three from Austria, two from Denmark, and one each from Sweden, Switzerland, Belgium, and the United States. All of the contributions and associated discussions are scheduled for publication in a single volume.

\section{DePt. OF Biology,}

Robert W. Pennak

UNIVERSITY OF COLORADO

\section{EDWIN BOOTH POWERS, 1880-1949}

Dr. Edwin Booth Powers, a former president of the Ecological Society, died very suddenly at his home on August 25, 1949 . He had been in good health until the moment of his death, caused by coronary thrombosis.

$\mathrm{He}$ was born on August 6, 1880, in Ellis County, Texas, the son of William Wilson and
Evaline Woods Powers. In 1918 he married Pauline Watkins; they had two children, William W. Powers, now of Philadelphia, and Edwine, now Mrs. Williston Cox of Louisville, Tennessee. His widow and children survive him.

He graduated from Trinity College, Texas, 